\title{
The Self-Fulfilling Prophecy's Effect on an Auditor's Issuance of a Going Concern Opinion
}

\author{
Jaysinha S. Shinde, Trey Stone and John Willems \\ Eastern Illinois University, Charleston, USA
}

Correspondence should be addressed to: Jaysinha S. Shinde; jsshinde@eiu.edu

Received date: 15 August 2013; Accepted date: 2 November 2013; Published date: 26 December 2013

Academic Editor: Nicoleta Radneantu

Copyright @ 2013. Jaysinha S. Shinde, Trey Stone and John Willems. Distributed under Creative Commons CC-BY 3.0

\begin{abstract}
This paper reports on the effect of a self-fulfilling prophecy on issuing a going concern opinion. A thorough analysis of the academic accounting literature and the popular press is performed to develop a better understanding of the rationales used by auditors in their decision to issue, or not to issue a going concern opinion. Based on the input of an expert panel, a literature review, and other quantitative criteria, the visibility and importance of these rationales is determined. A questionnaire is then developed to measure if the self-fulfilling prophecy has a role in auditors' decision to issue, or not to issue a going concern opinion. This questionnaire is administered to randomly selected CPAs in Illinois and also to auditing students at Eastern Illinois University. The psychometric properties of this questionnaire are thoroughly tested using statistical techniques like Cronbach's Alpha. The paper also uses statistical techniques including factor analysis, scree plots, and perceptual maps to understand the underlying dimensions of a CPA's decision to issue, or not to issue a going concern opinion. Finally, the paper uses statistical techniques such as t-testing to determine if significant differences exist between the respondents.
\end{abstract}

Keywords: self-fulfilling, accounting literature, auditing

\section{Introduction}

A self-fulfilling prophecy can be defined as a prediction that is made by a person, which fulfills itself because of the person's belief in the validity of that prediction. Thus, the belief of the person that a particular incident is going to occur, may itself lead to the incident occurring. A self-fulfilling prophecy is a prediction that directly or indirectly causes it to become true, by the very terms of the prophecy (Merton, 1968). Thomas (1928) defined a self-fulfilling prophecy as people defining situations to be real, in which case the situations became real in their consequences because of the belief that the

Cite this Article as: Jaysinha S. Shinde, Trey Stone and John Willems (2013)," The Self-Fulfilling Prophecy's Effect on an Auditor's Issuance of a Going Concern Opinion", Journal of Accounting and Auditing: Research \& Practice, Vol. 2013 (2013), Article ID 604086, DOI: 10.5171/2013. 604086 
people themselves had placed in the chances of that situation occurring. Merton further explains self-fulfilling prophecy by giving an example of a woman believing that her marriage will fail, which leads to a failure in her marriage, because of her belief in that prophecy. "The self-fulfilling prophecy is, in the beginning, a false definition of the situation evoking a new behavior which makes the original false conception come 'true'. This specious validity of the selffulfilling prophecy perpetuates a reign of error" (Merton, 1968:477).

Self-fulfilling prophecy can play a major role in the decision making process of an auditor to issue, or not to issue a going concern opinion. The resulting occurrence can have many unpronounced implications on society. Directly and indirectly, it can affect businesses, employees, competitors, suppliers, and other stakeholders. Thus, a key research question of this paper is whether auditors issue a going concern opinion, or fail to issue a going concern opinion because of the belief that issuance of a going concern opinion may itself lead to firm failure (a self-fulfilling prophecy)?

\section{Literature Review}

A going concern opinion is given by an external auditor, when he/she perceives that the audited client will not stay in business within the next 12 months or operating cycle, whichever is longer. That is, the going concern refers to a company's ability to continue functioning as a viable entity. Situations in which questions are raised about a firm's ability to continue in operations and meet its obligations as they become due are known as going-concern uncertainties and must therefore be recognized as such (Louwers, et al., 2011).

\section{The Self-Fulfilling Prophecy}

As the name implies, a self-fulfilling prophecy results when the predicted event occurs because it is assumed that it will happen. That is, the prediction of the actual event is the very reason why the event occurs. The prediction itself seems to change the way people in today's society think. "A selffulfilling prophecy is an assumption or prediction that, purely as a result of having been made, causes the expected or predicted event to occur and thus confirms its own 'accuracy'”' (Watzlawick, 1984: 392).

An example of a self-fulfilling prophecy would be a student who is concerned about his poor driving ability predicts that he will cause an accident. When the aforementioned student actually gets behind the wheel he is sure that he will cause a mishap, causing him to become nervous, and ultimately resulting in a car crash. This is the result of his prediction that he will crash because he is a bad driver. "For example, if someone assumes, for whatever reason, that he is not respected, he will, because of this assumption, act in such a hostile, overly sensitive, suspicious manner that he brings about that very contempt in others which 'proves' again and again his firmly entrenched conviction" (Watzlawick, 1984: 392).

In the auditing world, a self-fulfilling prophecy can arise when a given company has an external auditor issue a Going Concern Opinion (GCO). Sometimes, the GCO is also referred to as a Going Concern Qualification (GCQ). The GCO indicates (or prophesizes) that the company will fail within the next year. Thus, the GCO may create a selffulfilling prophecy by creating uncertainties in the company's ability to operate. "The essence of the crucial self-fulfilling prophecy argument is that the GCQ itself either brings about, or at least precipitates, bankruptcy. "It does this by adversely affecting the company's ability to either restructure its debt or raise badly needed new funds" (Citron and Taffler, 2001: 355). If a company could convince the external auditor not to issue the GCO, then the company might not be faced by these threats. It may not be ethical, but it does happen.

\section{The Domino Effects of the Issuing a Going Concern Opinion}

Issuance of a going concern opinion can have dramatic and tangible effects on a firm. 
These effects can be seen on employees, suppliers, competitors, owners, shareholders, creditors, community, etc.

\section{Employees}

Issuing a GCO may create employee morale problems because the employees believe that their company is going to fail within the next year. Employees might start to look for another job or even jump ship to a competitor if it does not break a contract that they are bound to. Employees want to feel secure in the sustainability of their company because if the company is able to withstand the test of time, then the employees working there will continue to get a paycheck. Many people and families are dependent on a paycheck and therefore will work hard and put forth effort in the tasks that they are assigned to on the job. With knowledge that the one thing that gives them motivation to get through the day will soon be gone, the desire to work hard is gone. People just will not care anymore. Moizer (1995) brings up the argument that by issuing a GCO, the auditor is morally responsible for the loss of jobs that may come about because of the issuance.

\section{Suppliers}

It is obvious that suppliers play a major role in the operations of a business, and without them it would be very difficult for a business to function. Since suppliers play such an integral role in a business, it is crucial for a company to maintain good relationships with its network of suppliers. From the supplier's point of view, the company ordering from them is a customer. While it is important to keep your customers, a firm may not want to associate itself with a company that has been issued a GCO. From the supplier's perspective, it might look bad to be dealing with a company that might be going bankrupt. The rest of the supplier's customers might suspect that the supplier itself is going bankrupt because of its business dealings with the company that got issued a GCO. The supplier might also not cut off business dealings completely with the company that got issued the GCO, but instead cut their line of credit so the company would have to pay immediately when the goods arrived. "It can also lead to problems with problems with customers and suppliers who are reluctant to deal with a firm whose continuing viability is questionable." (Citron and Taffler, 2001: 355).

\section{Competitors}

A company's major competitors should always be of major concern to top management and the board of directors. A company's major competitors are in constant battle for the market share of the industry that they are in. Furthermore, if the companies see another company struggling, for whatever reason, they might target it to try and make it go out of business. Company's might cut their prices or offer special deals for a limited time just because it could cause the company that's struggling to go bankrupt.

\section{Firm Owners}

Owners of a company, whether they are the original owners or they bought the company from someone else, might have doubts about the sustainability of the company if it were issued a GCO. Once the doubts are formed there is nothing stopping the owners from deciding to sell the company. The issuance of a GCO may psychologically and emotionally result in the owners being overly apathetic, or dramatic in running the company. These efforts alone may lead the company to failure.

\section{Share Price}

When a company is issued a GCO and the public finds this out, the share price can drop significantly. Investors lose confidence in the company and want to get out with whatever money they have left. The company still has the ability to recover, but some people are skittish and cannot stomach riding out the highs and lows of the stock market. Once it drops below a certain level people are willing to accept losses just to get out. 


\section{Creditors}

Banks, credit unions, and other lending institutions might develop doubts about a company's survival if it is issued a GCO. Any lender is concerned with a company's or individual's ability to repay the debt. Debt can add up and become overwhelming very easily and lenders usually do some sort of risk assessment to establish whether the client is a safe bet or not. Studies show that warning signals from auditors negatively influenced the loan officers' risk assessment, the interest rate premium, and the decision whether or not to grant the loan (GuiralContreras et al., 2007).

\section{Community}

If a company is a respected part of a community and it goes under, this will affect the community as a whole. As a valued member of a community, a company brings growth and development to its surrounding environment, but with its downfall these opportunities are lost.

\section{Top Management and Board of Directors}

The owners of a company want to project the company in the best possible light. If the board of directors or top management finds out they are about to be issued a GCO, they may try to persuade the auditor to act unethically. Auditors are supposed to act with integrity and be objective in their business dealings with their clients; however, sometimes this independence is compromised and the auditor succumbs to the temptation set before him or her.

\section{Rationale for Issuing a Going Concern Opinion (GCO)}

An external auditor issues a going concern opinion when she or he thinks that the company deserves one because of his or her duty to society. The auditor is not trying to condemn the company by issuing a GCO. There is a fine line between reporting objectively and causing widespread panic that the company is going under and everyone working there will be out of a job.
Causing panic and fear are not the goals of the auditor. "There must be a risk that any qualification about the company's financial viability, however it is expressed, will precipitate the company's collapse. There is a fine balance to be drawn between drawing proper attention to the conditions on which continuation of the business depends, and not thereby bringing the business down" (Cadbury Committee, 1992).

\section{Rationale for Not Issuing a Going Concern Opinion (GCO)}

The issuance of a GCO might affect the economy of the city or surrounding area that a company is part of. Suppliers and clients might stop doing business in that area if they foresee a company is having trouble surviving in the short-run. The auditor, especially in small communities, might know the owner of a business on a more personal note. Due to the self-fulfilling prophecy, the auditor may believe that the company would be ruined if he or she were to issue a GCO. Lastly, the auditor might be troubled because of the exposure cost and possibility losing the client. Auditors' exposure risk is related to the possibility of being sued by the client or another party not directly involved (LaSalle and Anandarajan, 1996). "While the company's auditor reports to its stockholders and owes a wider professional duty to society at large, the effective client is its management who determine both the auditor's tenure and remuneration" (Citron and Taffler, 2001: 354). All of these are reasons an auditor might be deterred from issuing a GCO.

\section{Ethical Decision Making in Issuing a GCO}

The auditor must issue a GCO if he or she thinks the situation calls for it. "The auditor should not refrain from qualifying his report if it is otherwise appropriate merely on the grounds that it may lead to the appointment of a receiver or liquidator" (APC, 1985). Moizer (1997), Mutchler (1984), and Sikka (1992) have all established evidence that drawing concern to a company's vitality and not pulling the plug on it is an issue in the 
auditing world and is of major concern to an auditor's process of decision making.

\section{Methodology}

The first step in the data collection process was done by developing and validating a survey on the self-fulfilling prophecy for auditors. After constructing the survey, it was administered to randomly selected CPAs in Illinois as well as currently enrolled auditing students at Eastern Illinois University. In terms of survey development and validation, statistical tools like factor analysis, scree plots, perceptual maps, and scale statistics were used. T-testing was also used to compare and contrast the differences between respondents.

The initial item pool was gathered by administering an open-ended survey to students and faculty, collecting items from the literature review, and performing a comprehensive web search (auditor blogs, PCAOB, AICPA, IIA, etc.). Seven broad categories were formed that encompassed most of the items in this initial pool: personal reasons, financial relationships, managerial relationships, self-fulfilling prophecy, societal benefits, legal issues, and firm recovery. From there, an instrument (Appendix 1) was developed and validated to measure why an auditor may not issue a GCO. This was done by checking its validity, reliability, and CMV (Common Method Variance). After that, the instrument was administered to CPAs and auditing students. The data was then collected and analyzed using statistical tools such as factor analysis (PCA - Varimax), scree plots, perceptual maps, scale statistics, and t-tests.

The content validity of the instrument was strong: all of the items/constructs measured all aspects of the larger concept. The final administration of the survey was understandable to the respondents and therefore validated the design of the instrument. Ecological validity was practical in that it has real world applications for auditors performing engagements. The external validity was also looked at and verified by being able to apply the results to a larger population (auditing students at Eastern compared to CPAs in Illinois).

Common Method Biases (also known as Common Method Variance or CMV) are created when several respondents have something in common that might significantly affect their answers, such as culture. Another example is that a respondent might feel uneasy about giving an honest response because they are afraid that their identity or identifying factors might be collected during the administration of the survey and linked to their responses. Yet another example is that a student taking the survey might get bored and fill out random answers in order to complete the survey faster. Finally the respondent may attach a significant level of importance to the items based on the order in which they are presented (Podaskoff, MacKenzie, Lee, and Podaskoff, 2003).

These examples of common method variances were relatively easy to overcome by applying the right techniques. By making the survey responses completely anonymous, it might make the respondents more likely to answer honestly (Nunally, 1978). By keeping the estimated survey completion time relatively short (for this study it was $<1$ minute) and by randomizing the order of the questions, you can overcome each of the variances created by losing respondents' attention span and item order respectively (Podaskoff, MacKenzie, Lee, and Podaskoff, 2003).

\section{Results}

The pilot study was administered to an auditing class at Eastern Illinois University. The response rate was $100 \%$ with 25 responses. The pilot study was utilized to understand the dimensionality of the construct. None of the items on the instrument were dropped during the pilot study.

The final administration was given to a sampling of $25 \%$ or 277 random CPAs in Illinois based if they had a public email address posted on the web (per 
yellowpages). Of these, there were 47 respondents with only 2 incomplete surveys; therefore the final sample size was 45 CPAs (16.24\%). Accounting students taking Auditing at Eastern also took the survey again. This time the response rate was still $100 \%$, but there were 33 responses (the entire class was there). None of the students' surveys were incomplete.

\section{Scale Statistics}

The results are in regards to the final administration. The study was reliable based on a Cronbach's Alpha of .752. This was confirmed with the Spearman-Brown Coefficient and the Guttman Split-Half Coefficient (Table 1).

Table 1

A. Reliability Statistics (Cronbach's Alpha)

\begin{tabular}{|c|c|c|}
\hline Cronbach's Alpha & Cronbach's Alpha Based on Standardized Items & N \\
\hline .752 & .732 & 7 \\
\hline
\end{tabular}

B. Reliability Statistics (Split)

\begin{tabular}{|l|c|}
\hline Spearman-Brown Coefficient & $\mathbf{8 3 0}$ \\
Guttman Split-Half Coefficient & .795 \\
\hline
\end{tabular}

\section{Factor Analysis}

Two underlying factors (dimensions) were found and confirmed by factor analysis and scree plot (Table 2). The two factors were labeled as Economic and Subjective respectively. The Economic factor included financial, legal, societal, self-fulfilling, and managerial reasons; while the Subjective factor included recovery and personal reasons (Figure 1).

Table 2: Factor Analysis (Varimax Rotation)

\begin{tabular}{|l|l|l|}
\hline Item & Economic Component & Subjective Component \\
\hline Financial & $\mathbf{. 8 2 2}$ & .236 \\
\hline Legal & $\mathbf{. 7 5 0}$ & .318 \\
\hline Societal & $\mathbf{7 1 3}$ & -.045 \\
\hline Self-fulfilling & $\mathbf{. 6 5 3}$ & -.050 \\
\hline Managerial & .496 & .369 \\
\hline Recovery & -.130 &. $\mathbf{8 1 0}$ \\
\hline Personal & .325 & .696 \\
\hline
\end{tabular}



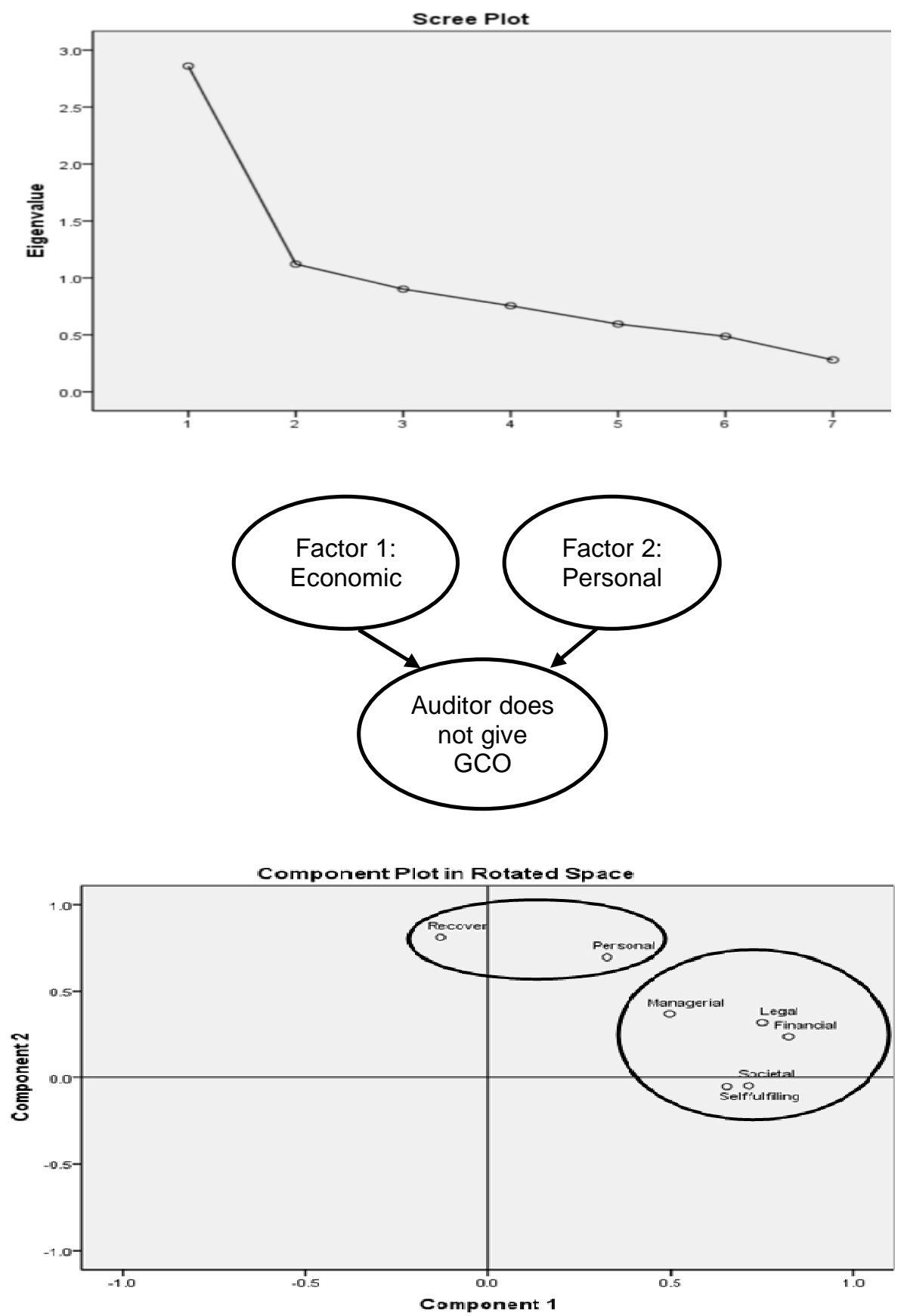

Figure 1: Scree Plot, Perceptual Map, \& Number of Factors

Jaysinha S. Shinde, Trey Stone and John Willems (2013), Journal of Accounting and Auditing: Research \& Practice, DOI: 10.5171/2013. 604086 
Table 3: Descriptive Statistics

Descriptive Statistics Student Sample (n = 33, 100\% Response Rate)

\begin{tabular}{|c|c|c|c|c|c|c|}
\hline & $\mathrm{N}$ & Minimum & Maximum & Mean & Std. Deviation & Variance \\
\hline Personal & 33 & 1.00 & 7.00 & 2.7273 & 1.54662 & 2.392 \\
\hline Financial & 33 & 1.00 & 7.00 & 3.3030 & 1.91188 & 3.655 \\
\hline Managerial & 33 & 1.00 & 5.00 & 2.0000 & .82916 & .688 \\
\hline Self-Fulfilling & 33 & 1.00 & 7.00 & 5.6061 & 1.80172 & 3.246 \\
\hline Societal & 33 & 1.00 & 7.00 & 5.8788 & 1.53618 & 2.360 \\
\hline Legal & 33 & 1.00 & 7.00 & 4.5152 & 1.69781 & 2.883 \\
\hline Recovery & 33 & 1.00 & 7.00 & 5.5455 & 1.82159 & 3.318 \\
\hline
\end{tabular}

Descriptive Statistics CPA Sample (n = 277)

(47 Responses, 2 incomplete, final $=45,16.24 \%$ Response Rate)

\begin{tabular}{|c|c|c|c|c|c|c|}
\hline & $\mathrm{N}$ & Minimum & Maximum & Mean & Std. Deviation & Variance \\
\hline Personal & 45 & 1.00 & 5.00 & 2.8667 & 1.63207 & 2.664 \\
\hline Financial & 45 & 1.00 & 7.00 & 4.9111 & 2.28456 & 5.219 \\
\hline Managerial & 45 & 1.00 & 7.00 & 2.2000 & 1.14018 & 1.300 \\
\hline Self-Fulfilling & 45 & 1.00 & 7.00 & 5.4444 & 1.65907 & 2.753 \\
\hline Societal & 45 & 1.00 & 7.00 & 5.6889 & 1.48970 & 2.219 \\
\hline Legal & 45 & 1.00 & 7.00 & 5.4667 & 2.09545 & 4.391 \\
\hline Recovery & 45 & 2.00 & 7.00 & 2.5333 & 1.05744 & 1.118 \\
\hline
\end{tabular}


Table 4: Results: Independent Samples Test

\begin{tabular}{|c|c|c|c|c|c|c|c|c|c|c|}
\hline & \multicolumn{2}{|c|}{$\begin{array}{c}\text { Levene's } \\
\text { Test for } \\
\text { Equality of } \\
\text { Variances }\end{array}$} & \multicolumn{7}{|c|}{ t-test for Equality of Means } \\
\hline & & \multirow[b]{2}{*}{$\mathbf{F}$} & \multirow[b]{2}{*}{ Sig. } & \multirow[b]{2}{*}{$\mathbf{t}$} & \multirow[b]{2}{*}{ df } & \multirow{2}{*}{$\begin{array}{l}\text { Sig. (2- } \\
\text { tailed) }\end{array}$} & \multirow{2}{*}{$\begin{array}{c}\text { Mean } \\
\text { Difference }\end{array}$} & \multirow{2}{*}{$\begin{array}{l}\text { Std. Error } \\
\text { Difference }\end{array}$} & \multicolumn{2}{|c|}{$\begin{array}{c}95 \% \\
\text { Confidence } \\
\text { Interval of the } \\
\text { Difference } \\
\end{array}$} \\
\hline & & & & & & & & & Lower & Upper \\
\hline \multirow[t]{2}{*}{ Personal } & $\begin{array}{l}\text { Equal variances } \\
\text { assumed }\end{array}$ & 1.774 & .187 & .381 & 76 & .704 & .13939 & .36593 & -.58941 & .86820 \\
\hline & No Equal variances & & & .384 & 71.113 & .702 & .13939 & .36287 & -.58414 & .86293 \\
\hline \multirow[t]{2}{*}{ Financial } & $\begin{array}{l}\text { Equal variances } \\
\text { assumed }\end{array}$ & 1.731 & .192 & 3.286 & 76 & .002 & 1.60808 & .48944 & .63327 & 2.5828 \\
\hline & No Equal variances & & & 3.377 & 74.608 & .001 & 1.60808 & .47618 & .65940 & 2.5567 \\
\hline \multirow[t]{2}{*}{$\begin{array}{l}\text { Manageria } \\
1\end{array}$} & $\begin{array}{l}\text { Equal variances } \\
\text { assumed }\end{array}$ & 1.521 & .221 & .855 & 76 & .395 & .20000 & .23396 & -.26597 & .66597 \\
\hline & No Equal variances & & & .897 & 75.999 & .373 & .20000 & .22298 & -.24411 & .64411 \\
\hline \multirow[t]{2}{*}{$\begin{array}{l}\text { Self- } \\
\text { Fulfilling }\end{array}$} & $\begin{array}{l}\text { Equal variances } \\
\text { assumed }\end{array}$ & .018 & .894 & -.410 & 76 & .683 & -.16162 & .39433 & -.94699 & .62376 \\
\hline & No Equal variances & & & -.405 & 65.695 & .687 & -.16162 & .39942 & -.95916 & .63592 \\
\hline \multirow[t]{2}{*}{ Societal } & $\begin{array}{l}\text { Equal variances } \\
\text { assumed }\end{array}$ & .011 & .917 & -.549 & 76 & .585 & -.18990 & .34594 & -.87890 & .49910 \\
\hline & Equal variances & & & -.546 & 67.877 & .587 & -.18990 & .34760 & -.88355 & .50375 \\
\hline \multirow[t]{2}{*}{ Legal } & $\begin{array}{l}\text { Equal variances } \\
\text { assumed }\end{array}$ & .234 & .630 & 2.142 & 76 & .035 & .95152 & .44416 & .06690 & 1.8361 \\
\hline & Equal variances & & & 2.213 & 75.188 & .030 & .95152 & .43003 & .09488 & 1.8081 \\
\hline \multirow[t]{2}{*}{ Recovery } & $\begin{array}{l}\text { Equal variances } \\
\text { assumed }\end{array}$ & 14.63 & .000 & 9.192 & 76 & .000 & -3.01212 & .32770 & 3.66479 & -2.3594 \\
\hline & Equal variances & & & 8.506 & 47.654 & .000 & -3.01212 & .35412 & 3.72426 & -2.2999 \\
\hline
\end{tabular}




\section{Discussion \& Conclusion}

This section is dedicated to interpreting the results of the statistical analysis. It also lists the contributions, limitations, and ideas for future research. For example, the survey should indicate that CPAs have deliberated on ethical issues surrounding an issuance of a going concern opinion. One of these reasons could be the effect of the selffulfilling prophecy on the firm's future after the issuance of a going concern opinion.

After the study was conducted, CPAs responded that the self-fulfilling prophecy may play a role in auditors not issuing a going concern opinion. CPAs also felt that financial, societal benefit, and legal issues could play a role in auditors not issuing a going concern opinion. CPAs (as opposed to students) felt that legal and financial issues will have an impact in issuing a going concern opinion.

Students also responded that the selffulfilling prophecy may have an impact on why an auditor may choose not to give a GCO. Students differed on financial, legal, and recovery rationale for why a going concern opinion may not be given (significant at .05 alpha level). Students felt more empathetic (or optimistic) about a firm's ability to bounce back. The difference between CPAs and students for the recovery rationale was significant even at a .01 alpha level.

The ability of the students to feel more optimistic or empathetic about the firm's ability to recover could be explained due to the lack of actual real world experience of the students as compared to the professionals (CPAs). It would be interesting to do a longitudinal study on these students (over time) to see if their responses would change over a period of time (e.g. after Year 3, Year 5 , Year $10 \ldots$ so on...).

This study had several contributions to the research already done on the subject. The survey instrument was a designed and validated reliable instrument to measure underlying rationale of why an auditor may not issue a going concern opinion. The response rate was sufficient enough to provide for thorough data analysis and accurate results.

This was an empirical study done on a vastly unexplored topic. This study has practical applications: CPAs know from experience and anecdotal evidence that giving a GCO is not a completely objective process, which is confirmed by this study. The study also has pedagogical applications for those in the classroom.

Possible limitations of this study include, but are not limited to the following: the lack of a bigger sample size for the CPAs (reduced external validity), the student sampling was convenient and selected (this also reduced external validity), and time and resource constraints. By overcoming these limitations, the overall study would typically increase in reliability and validity and therefore be more credible. However, limitations will always exist in any study because there is always something that could be improved or done better.

Possible directions for future research include increasing the CPA sample size and expanding the range to cover CPAs in other states across the nation. By not limiting the CPA population to a selective sample, there would be a lot of external validity for the study. As a second part of this exploratory study, the authors have already embarked on this project.

It would also be interesting if this study could be done in other countries around the world and then compared and contrasted to results here in the United States. By applying the study findings internationally, one could find out if the results hold true in other countries. What is true here in the U.S., may not neccesarily be applicable in other countries, particularly countries with different sets of regulations. For example, countries with political instability could have a very different scenario about going concerns than the United States. Also, countries where typically the government steps in with 
financial aid to rescue firms could also present a completely different picture than in the United States.

As for the student aspect, students could be compared at other universities here in the United States and internationally as well. The results of this study could be of particular use to the PCAOB when setting new standards for auditing. It could also be used to look at the other reasons an auditor might hesitate when issuing a going concern opinion such as legal issues.

\section{References}

1.Auditing Practices Committee (APC) (1985). Auditing Guideline - The Auditor's Considerations in Respect of Going Concern (APC, London).

2.Benson, J. \& Clark, F. (1982). A Guide for Instrument Development and Validation. The American Journal of Occupational Therapy, 36(12), 789-800.

3. Cadbury Committee (1992). Report of the Committee on the Financial Aspects of Corporate Governance (Gee, London).

4.Citron, D. and Taffler, R. (2001). 'Ethical Behavior in the U.K. Audit Profession: The Case of the Self-Fulfilling Prophecy Under Going-Concern Uncertainties', Journal of Business Ethics 29, 353-363.

5. Guiral-Contreras, A., Gonzalo-Angulo, J., and Rodgers, W. (2007). 'Information Content and Recency Effect of the Audit Report in Loan Rating Decisions', Accounting and Finance 47(2), 285-304.

6. LaSalle, R. and Anandarajan, A. (1996). 'Auditors' Views on the Type of Audit Report Issued to Entities with Going Concern Uncertainties', Accounting Horizons 10, 5172.

7.Louwers, T., Ramsey, R., Sinason, D., Strawser, J., and Thibodeau, J. (2011).
Auditing and Assurance Services, $4^{\text {th }}$ Edition, New York: McGraw-Hill.

8. Merton, R. (1968). Social Theory and Social Structure. New York: Free Press.

9. Moizer, P. (1995). 'An Ethical Approach to the Choices Faced by Auditors', Critical Perspectives on Accounting (October), 415431.

10.Moizer, P. (1997). 'Independence', in M. Sherer and S. Turley (eds.), Current Issues in Auditing, 3rd edition (Paul Chapman Publishing, London), Ch 3.

11.Mutchler, J. (1984). 'Auditors' Perceptions of the Going Concern Opinion Decision', Auditing: A Journal of Practice and Theory (Fall), 17-29.

12.Nunnally, J. (1978). Psychometric Theory, 2nd Edition. New York, McGraw-Hill.

13.Podsakoff, P., MacKenzie, S., Lee, J., \& Podsakoff, N. (2003). "Common method biases in behavioral research: a critical review of the literature and recommended remedies". The Journal of Applied Psychology: 88, 879-903.

14.Sikka, P. (1992). 'Audit Policy Making in the U.K.: The Case of "The Auditor's Considerations in Respect of Going Concern"', The European Accounting Review, 349-392.

15.Spector, P. (1981) Research Designs. California: Sage Publications.

16.Thomas, W. (1928). The Child in America: Behavior Problems and Programs. New York: Alfred A. Knopf.

17.Watzlawick, P. (1984). Self-Fulfilling Prophecies, In The Production of Reality: Essays and Readings on Social Interaction by O’Brien, J., 5th Edition, California: Pine Forge Press. 


\section{Appendix 1}

\section{Rationale for Not Giving a Going Concern}

As an auditor you are auditing a firm whose financial statements indicate that there is a substantial doubt about the entity's ability to continue as a going concern for the next year.
In such a scenario, what is the probability that you would hesitate in issuing a going concern opinion for the following reasons:

1. Personal reasons

\begin{tabular}{|c|c|c|c|c|c|c|}
\hline \begin{tabular}{l}
\multicolumn{1}{c}{1} \\
Absolutely \\
Disagree
\end{tabular} & $\begin{array}{l}2 \\
\text { Strongly } \\
\text { Disagree }\end{array}$ & $\begin{array}{c}3 \\
\text { Disagree }\end{array}$ & $\begin{array}{c}4 \\
\text { Neutral }\end{array}$ & $\begin{array}{c}5 \\
\text { Agree }\end{array}$ & $\begin{array}{c}\text { 6 } \\
\text { Strongly } \\
\text { Agree }\end{array}$ & \begin{tabular}{l}
\multicolumn{7}{c}{7} \\
Absolutely \\
Agree
\end{tabular} \\
\hline $\begin{array}{l}\text { Financial } \\
\text { bsolutely } \\
\text { isagree }\end{array}$ & $\begin{array}{l}\text { lationship w } \\
2 \\
\text { Strongly } \\
\text { Disagree }\end{array}$ & $\begin{array}{l}\text { the firm } \\
\mathbf{3} \\
\text { Disagree }\end{array}$ & $\begin{array}{c}4 \\
\text { Neutral }\end{array}$ & $\begin{array}{c}5 \\
\text { Agree }\end{array}$ & $\begin{array}{c}\text { 6 } \\
\text { Strongly } \\
\text { Agree }\end{array}$ & \begin{tabular}{l}
\multicolumn{7}{c}{7} \\
Absolutely \\
Agree
\end{tabular} \\
\hline $\begin{array}{l}\text { solutely } \\
\text { sagree }\end{array}$ & $\begin{array}{l}\text { relationship } \\
2 \\
\text { Strongly } \\
\text { Disagree }\end{array}$ & $\begin{array}{l}\text { ith the firm } \\
\mathbf{3} \\
\text { Disagree }\end{array}$ & $\begin{array}{c}4 \\
\text { Neutral }\end{array}$ & $\begin{array}{c}5 \\
\text { Agree }\end{array}$ & $\begin{array}{c}\text { Strongly } \\
\text { Stron } \\
\text { Agree }\end{array}$ & $\begin{array}{l}\text { 7 } \\
\text { Absolutely } \\
\text { Agree }\end{array}$ \\
\hline
\end{tabular}

4. Self-fulfilling prophecy that the going concern opinion given by you will by itself cause the firm to fail.

1

Absolutely Strongly Disagree Neutral

Disagree Disagree

$\begin{array}{cc}3 & 4 \\ \text { Disagree } & \text { Neutral }\end{array}$

5

Agree Strongly Absolutely

5. Societal Benefit

Absolutely Strongly

3

4

Disagree

Disagree

Disagree Neutral

5

Agree

Agree

Agree

6. Legal issues

1

2

Absolutely Strongly

3

4

Disagree

Disagree

Disagree Neutral

7. Knowledge or belief that the firm may recover

$\begin{array}{lccc}1 & 2 & 3 & 4 \\ \text { Absolutely } & \text { Strongly } & \text { Disagree } & \text { Neutral } \\ \text { Disagree } & \text { Disagree } & & \end{array}$

$\begin{array}{ccc}5 & 6 & 7 \\ \text { Agree } & \text { Strongly } & \text { Absolutely } \\ \text { Agree } & \text { Agree }\end{array}$

